\title{
Ground-Water Problems
}

in theVicinity of Moscow, Latah County, Idaho

By P. R. STEVENS

ᄃ O N T R I B U T I O N S T O H Y D O L O G Y

GEOLOGICAL SURVEY WATER-SUPPLY PAPER 1460-H

Prepared in cooperation with the Idaho State Department of Reclamation and the city of Moscow

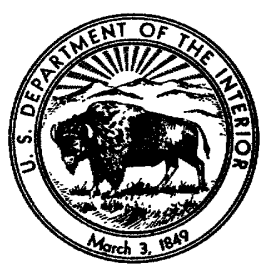




\title{
UNITED STATES DEPARTMENT OF THE INTERIOR
}

\author{
FRED A. SEATON, Secretary
}

\section{GEOLOGICAL SURVEY}

Thomas B. Nolan, Director

For sale by the Superintendent of Documents, U.S. Government Printing Office Washington 25, D.C. 


\section{CONTENTS}

\begin{tabular}{|c|c|}
\hline \multirow{2}{*}{\multicolumn{2}{|c|}{ Abstract. }} \\
\hline & \\
\hline Introduction & \\
\hline Purpose and scope of report & \\
\hline Location of area & 326 \\
\hline Well-numbering system & 327 \\
\hline Previous investigations & 328 \\
\hline eography & \\
\hline rraphic setting & 328 \\
\hline $\begin{array}{c}{ }^{\prime} \\
\end{array}$ & 329 \\
\hline -й & 330 \\
\hline 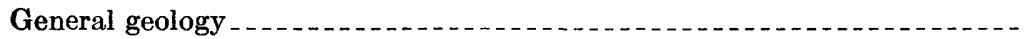 & 332 \\
\hline tting & 332 \\
\hline ers & 335 \\
\hline d aquifers.-. & \\
\hline 只 & 337 \\
\hline ter & 337 \\
\hline - & 339 \\
\hline d water & 339 \\
\hline ater & 340 \\
\hline els & 340 \\
\hline 思 & 341 \\
\hline piration & 341 \\
\hline charge & 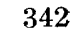 \\
\hline ity of the water & 34 \\
\hline ( & 345 \\
\hline nand & 345 \\
\hline sources & 346 \\
\hline 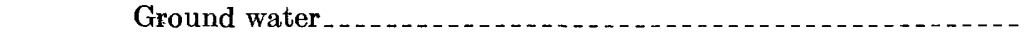 & 34 \\
\hline - - & 347 \\
\hline arge of ground water & 34 \\
\hline ogs and records of wells & 348 \\
\hline ummary & 348 \\
\hline & 351 \\
\hline & \\
\hline
\end{tabular}




\section{ILLUSTRATIONS}

Plate 13. Map of Moscow basin showing recharge area and location of wells.

FIGURE 25. Index map of Idaho showing area covered by this report. . . . 327

26. Well-numbering system

27. Precipitation at Moscow, 1892-1955

28. Hypothetical east-west section through Moscow basin_._._. 333

29. Hypothetical north-south section through Moscow basin_...- 334

30. Composite stratigraphic section of the Latah formation and intercalated Columbia River basalt _._.

31. Hydrograph well $39 \mathrm{~N}-5 \mathrm{~W}-10$ acl $\ldots \ldots \ldots$

32. Hydrograph of well $39 \mathrm{~N}-5 \mathrm{~W}-7 \mathrm{ddl} \ldots \ldots \ldots$

\section{TABLES}

Table 1. Logs of wells. 


\title{
CONTRIBUTIONS TO HYDROLOGY
}

\section{GROUND-WATER PROBLEMS IN THE VIGINITY OF MOSCOW, LATAH GOUNTY, IDAHO}

\author{
By P. R. Stevens
}

\section{ABSTRACT}

The water supply in the Moscow area in southwestern Latah County, northern Idaho, presents a potentially critical problem because the present supply is barely adequate and the total supply available within the Moscow basin probably will become inadequate in the near future. The area includes about 60 square miles in the Moscow basin. An evaluation of the available geologic and hydrologic data, an estimate of the amount of usable ground water, and a description of the occurrence of ground water in the Moscow basin are presented in this report to assist city and State officials in appraising supplemental sources of water for municipal and other needs in Moscow and vicinity.

Crystalline rocks of low permeability crop out in highlands north, east, and south of Moscow and are believed to underlie younger rocks throughout the basin. At places sand, gravel, silt, and clay resulting from weathering and erosion overlie the crystalline rocks, but at other places they interfinger with the Columbia River basalt and constitute the Latah formation. These sedimentary deposits form a permeable zone through which water moves from the surface and becomes confined in sand beds of the Latah formation and permeable zones in the Columbia River basalt. Quaternary eolian and fluviatile sediments compose the surface deposits which contain unconfined ground water, but the yield of water is small.

Available data are insufficient to determine accurately the average annual recharge to the artesian aquifers. Natural and artificial discharge from the artesian aquifers in 1955 exceeded the recharge, and records of water levels in artesian wells have shown an annual decline for many years. The amount of water carried off by streams from the Moscow basin is estimated at 12,000 acre-feet yearly.

The water in both the artesian and water-table aquifers is of the calcium bicarbonate type: It is moderately hard and contains relatively high concentrations of iron and silica. Reduction of the hardness and the iron content would make the water more suitable for municipal, domestic, and industrial use.

The demand for water in Moscow in 1970 is expected to be double that of 1955, thereby increasing the rate of overdraft on the artesian aquifers. Surface water is suggested as a direct supplemental source and for possible artificial recharge of the artesian aquifers as a means of increasing the yield of the present source. 


\section{INTRODUCTION}

\section{PURPOSE AND SCOPE OF REPORT}

Water-level records for artesian wells at Moscow, in the Moscow basin, Latah County, Idaho, show a large cumulative and continuing decline in artesian pressure for a period of more than 60 years. Beginning several summers preceding this investigation, restrictions have been imposed on the use of municipal water. A new well, drilled late in 1955, partly relieved the water shortage in 1956, but continued growth of population, business, and industry will require further additions to the public water supply. The University of Idaho at Moscow has its own wells for water supply, but these and the city wells tap the same artesian basin.

At the request of the city of Moscow and the Idaho State Reclamation Engineer, the U.S. Geological Survey made a reconnaissance ground-water investigation in the Moscow basin during October and November 1955. The fieldwork on which this report is based included an evaluation of the available hydrologic and geologic data, an estimate of the amount of ground water available annually in relation to the amount used, and an appraisal of the methods for disposal of unused water.

The purpose of this report is to assist city and State officials and present or potential users of ground water in appraising possible supplemental sources of water and in determining the need for a more intensive investigation of the water resources.

Fieldwork in the Moscow basin and the preparation of this report were part of the program of ground-water studies by the Geological Survey in cooperation with the State of Idaho and the city of Moscow. This investigation was under the direct supervision of R. L. Nace, formerly district geologist, Boise, Idaho.

The Department of Mines and Geology and the Department of Agricultural Engineering of the University of Idaho, city officials of Moscow, well drillers, and the U. S. Soil Conservation Service furnished much useful data for this investigation.

\section{LOCATION OF AREA}

Moscow is in the Moscow basin in southwestern Latah County, northern Idaho (fig. 25), about 23 miles north of Lewiston, Idaho, 9 miles east of Pullman, Wash., and about three-quarters of a mile east of the boundary between Idaho and Washington. U.S. Highway 95 , the main artery of north-south travel in western Idaho, passes through Moscow. Idaho Highway 8 connects Moscow with Pullman, Wash., and with towns to the east. Many county and logging roads traverse the Moscow basin. The city is served by the 
Union Pacific Railroad, Northern Pacific Railway, and Great Northern Railway.

This report covers the area in the upstream basins of Paradise Creek and the South Fork of the Palouse River in Idaho (pl. 13), between the State boundary on the west and the drainage divides on the north, east, and south. The total area is slightly more than 60 square miles, or about 40,000 acres, and includes all land in which recharge to ground water in the Idaho part of the Moscow basin is believed to occur.

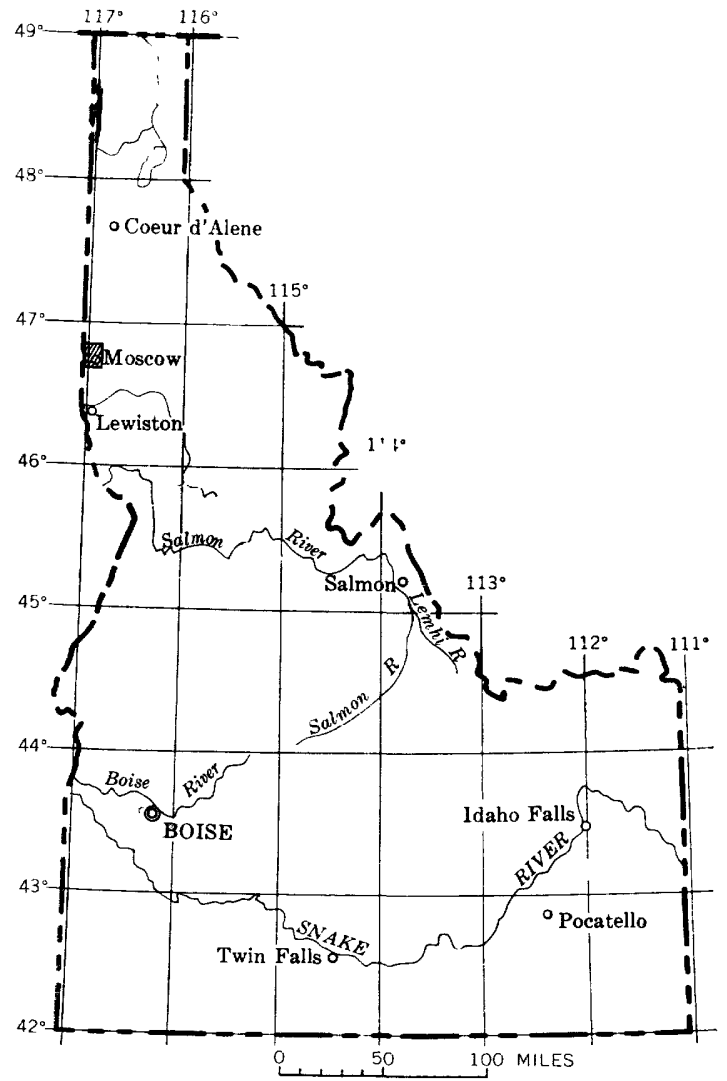

Fradre 25.-Index map of Idaho showing area covered by this report.

WELL-NUMBERING SYSTEM

The well-numbering system used by the Geological Survey in Idaho indicates the locations of wells within official rectangular subdivisions of the public lands, with reference to the Boise base line and meridian. The first two segments of the well number designate the township and range. The third segment is the section number, 
followed by two letters and a numeral, which indicate the quarter section, the 40-acre tract of land, and the serial number of the well within the tract. Quarter sections are lettered $a, b$, c, and $d$ in counterclockwise order, starting from the northeast quarter of each section (see fig. 26). Within the quarter sections, 40 -acre tracts are lettered in the same manner. The serial number following the letters indicates the order in which the wells were first visited within the 40 -acre tracts. For example, well $39 \mathrm{~N}-5 \mathrm{~W}-12 \mathrm{dd} 1$ is in the $\mathrm{SE} 1 / 4 \mathrm{SE} 1 / 4$ sec. 12 , T. 39 N., R. 5 W., and is the well first visited in that tract.

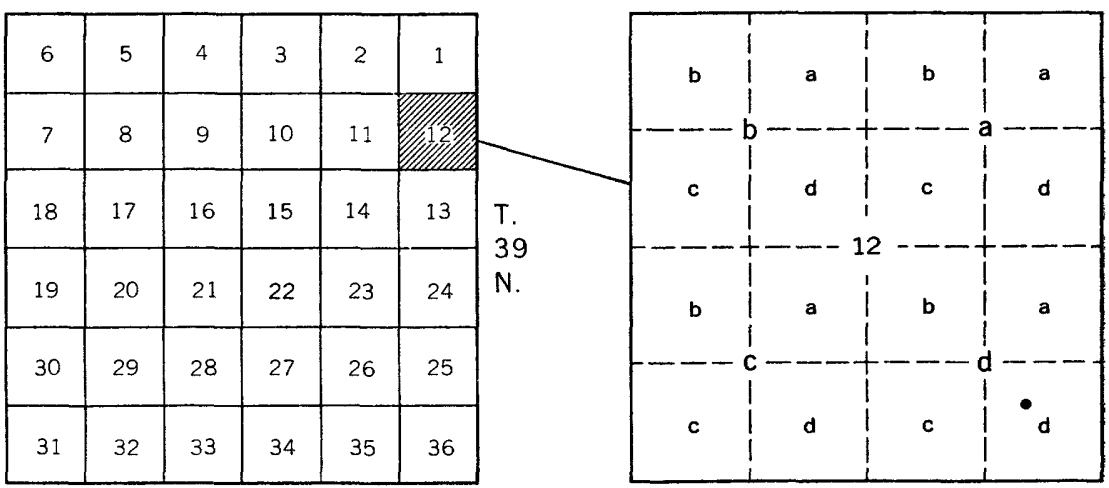

R. 5 W.

Sec. 12

Figtre 26.-Well-numbering system used by the Geological Survey in Idaho, showing location of well $39 \mathrm{~N}-5 \mathrm{~W}-12 d \mathrm{~d}$.

The township, range, and section parts of the well number are not shown on plate 13 .

\section{PREVIOUS INVESTIGATIONS}

M. M. Johnson and C. F. Myrene described the geology and mineral resources of an area in the vicinity of Moscow (written communication, Nov. 1955). Laney, Kirkham, and Piper (1923) described the ground-water geology of the Moscow basin and estimated the yearly amount of potential ground-water recharge. The most detailed published geologic study of Latah County is by Tullis (1944). Ground-water conditions in the vicinity of Pullman, Wash., in the westward extension of the Moscow basin, are described by Foxworthy and Washburn (1957).

\section{GEOGRAPHY}

\section{PHYSIOGRAPHIC SETTING}

The Moscow basin is in the Walla Walla Plateau section of the Columbia Plateaus province (Fenneman, 1917), about 50 miles west of the Coeur d'Alene Mountains. The city of Moscow is near the 
east end of an ancient river valley which was partly filled with sedimentary materials and basaltic lava flows. The altitude of the area ranges from 2,570 feet at Moscow to 4,280 feet at the summit of Moscow Mountain (pl. 13). Bordering the Moscow basin is the Palouse Range, including Moscow Mountain, on the north; Tomer Butte and the adjacent highlands on the east; and Paradise Ridge on the south. These highlands are erosional remnants of ancient and more rugged mountains. The slopes of Moscow Mountain and the Palouse Range are steep near the summits but gentle at lower altitudes where they merge with the rolling topography of the basin. A thick coniferous forest covers much of the highlands and helps stabilize the soil on steep slopes. The slopes of Tomer Butte and the east half of Paradise Ridge are moderately steep and have a scattered stand of ponderosa pine. The highlands between Tomer Butte and Moscow Mountain and the west half of Paradise Ridge slope gently to moderately. Much of the slope is farmed, and winter wheat is the principal crop.

The surface of the basin that is bordered on three sides by the Palouse Range consists of moderately rolling broad, rounded hills on which the topographic relief exceeds 200 feet at some places. These hills consist in large part of loess and many dune features. They are part of the Palouse Hills, a term often used for this rolling topography in the Palouse River basin in Washington and adjacent areas, and encroach the lower flanks of the Palouse Range.

The main stream, the South Fork of the Palouse River, rises on the southwestern slopes of Moscow Mountain; Crumerine Creek rises on the southern slopes of The Twins, two prominent peaks in the Palouse Range; and Paradise Creek rises farther west on the southern slopes of the Palouse Range (pl. 13). In the valley-head areas the streams have steep gradients and narrow, steep walls. In the lowland, the stream gradients are gentle.

\section{CLIMATE}

Moscow has moderately cold winters and warm summers, as indicated by the following table. The mean annual temperature at Moscow is $47.1^{\circ} \mathrm{F}$; the highest temperature recorded was $105^{\circ} \mathrm{F}$, and the lowest $-30^{\circ} \mathrm{F}$. Temperatures higher than $100^{\circ}$ are rare. The frost-free season averages about 150 days but has varied from 83 (1935) to 201 days (1940).

The normal annual precipitation at Moscow is 21.7 inches, of which about half falls from November through February. About three-quarters falls from October through April, and only about one-quarter during the growing season, May through September. The intensity of rainfall at Moscow is usually very low, but occa- 
sionally it is so high that heavy runoff causes considerable soil erosion.

Mean monthly temperature and normal precipitation at Moscow, 1892-1955

[From records of the U.S. Weather Bureau]

\begin{tabular}{|c|c|c|c|}
\hline \multirow{2}{*}{ Month } & \multicolumn{2}{|c|}{ Precipitation } & \multirow{2}{*}{$\begin{array}{l}\text { Mean tempera- } \\
\text { ture }\left({ }^{\circ} \mathrm{F}\right)\end{array}$} \\
\hline & Normal (inches) & $\begin{array}{l}\text { Percent of an- } \\
\text { nual total }\end{array}$ & \\
\hline $\begin{array}{l}\text { Jan } \\
\text { Feb } \\
\text { Mar } \\
\text { Apr } \\
\text { May } \\
\text { June } \\
\text { July } \\
\text { Aug } \\
\text { Sept } \\
\text { Oct } \\
\text { Nov } \\
\text { Dec }\end{array}$ & $\begin{array}{l}2.78 \\
2.11 \\
2.16 \\
1.59 \\
1.87 \\
1.47 \\
.56 \\
.61 \\
1.27 \\
1.68 \\
2.86 \\
2.74\end{array}$ & $\begin{array}{l}\text { 12. } 81 \\
9.72 \\
9.96 \\
7.33 \\
8.62 \\
6.77 \\
2.58 \\
2.81 \\
5.85 \\
7.74 \\
13.18 \\
12.63\end{array}$ & $\begin{array}{l}\text { 28. } 2 \\
31.7 \\
38.4 \\
46.2 \\
53.0 \\
59.3 \\
67.2 \\
66.1 \\
57.8 \\
48.9 \\
\text { 37. } 7 \\
\text { 30. } 8\end{array}$ \\
\hline Average annual & 21. 70 & $-\ldots$ & 47. 1 \\
\hline
\end{tabular}

The precipitation increases with altitude and probably exceeds 23 inches on the upper part of Moscow Mountain and 22 inches on the Palouse Range, Paradise Ridge, and the upper part of Tomer Butte. For the purpose of this report the average annual precipitation on the highland area is conservatively estimated to be 22 inches.

Records of precipitation at Moscow disclose cyclic fluctuations, with both short- and long-term cumulative departures from normal (fig. 27). One long-term wet period began in 1899 and ended about 1913, with a cumulative excess precipitation of about 19 inches. In a drier period beginning in 1914 and ending in 1944, the cumulative deficiency was about 23 inches.

The prevailing winds are from the west except in December, January, and February, when they are from the east. Wind velocities are low, and sustained velocities commonly are about 5 or 6 miles per hour. The wind is rarely destructive. Summer thunderstorms are infrequent and usually mild.

\section{USE OF WATER}

Water for the public supply of Moscow, for the University of Idaho, and for a few farms and rural residences is obtained from artesian aquifers. A shallow nonartesian aquifer supplies water for most rural, domestic, and stock use, and for a flour mill in the city. Little surface water is used except at a small recreational reservoir on the South Fork of the Palouse River about 4 miles east-northeast of Moscow (pl. 13). 


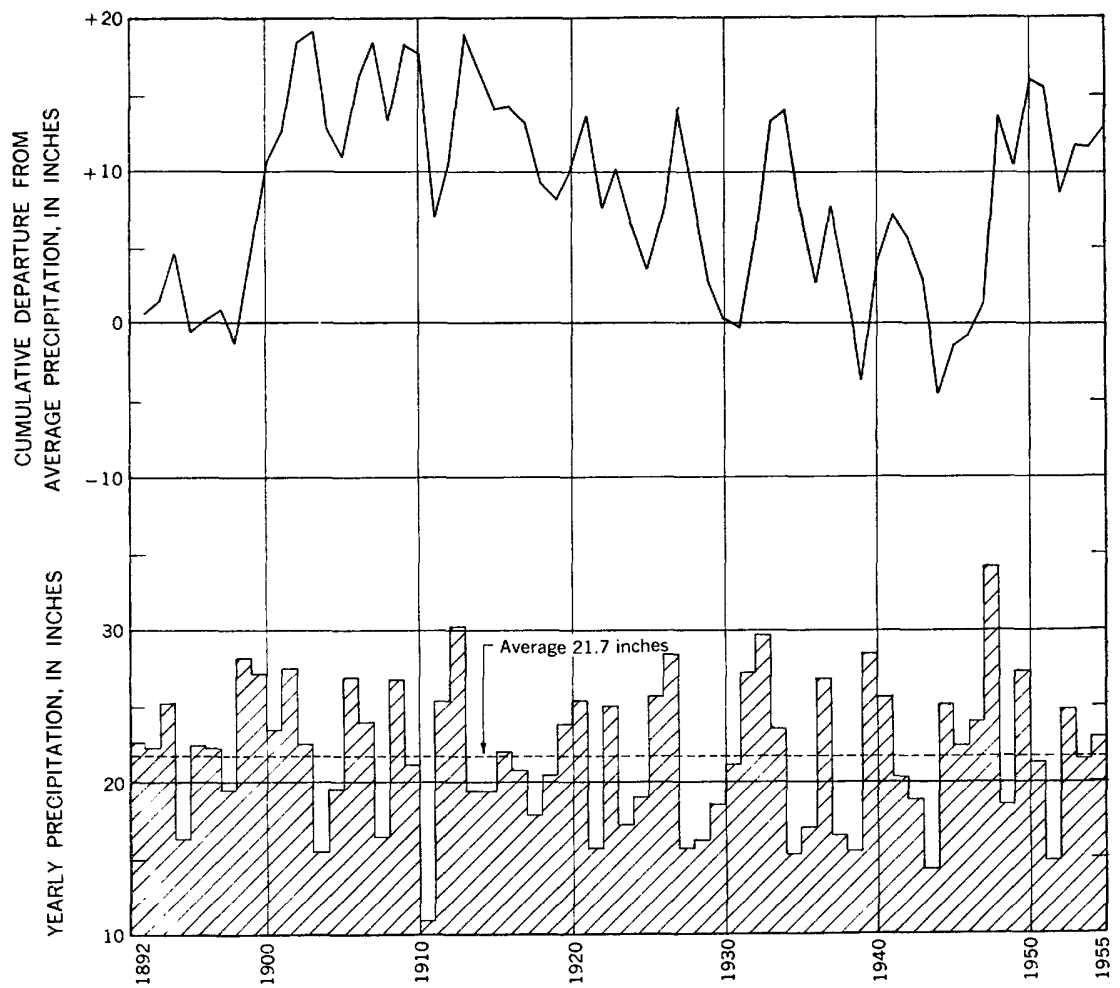

FIGURe 27.-Annual precipitation and cumulative departure from average precipitation at Moscow, 1892-1955.

Water withdrawals from the artesian aquifers, shown in the following table, are based on pumping records of the city of Moscow

Estimated ground-water withdrawal from artesian aquifers in the Moscow basin $1951-55$

\begin{tabular}{|c|c|c|}
\hline Year & Gallons (millions) & Increase (percent) \\
\hline 1951 & $\begin{array}{r}660 \\
675 \\
685 \\
700 \\
1720\end{array}$ & $\begin{array}{l}-7 . \\
1.4 \\
2.1 \\
2.1\end{array}$ \\
\hline
\end{tabular}

1720 million gallons $=$ about 2,200 acre-feet.

wells for 1951-55; on meter readings of the discharge from the wells at the University of Idaho from February 1955 through October 25, 1955 ; and on estimates of withdrawals from other wells, which have 
an assumed average use of $300 \mathrm{gpd}$ (gallons per day) per well. The estimated average daily withdrawal from the artesian aquifers during 1955 was 1,530,000 gallons by the city of Moscow, 425,000 by the University of Idaho, and 6,000 by all other users. The rounded total is 2 million gallons daily. The average monthly withdrawal in 1955 was about 60 million gallons, and the total during the year was about 720 million.

\section{GENERAL GEOLOGY}

\section{GEOLOGIC SETTING}

The geologic features that control the water supply of the Moscow basin are quite simple in general but complex in detail; only the general features are discussed here. Two groups of rocks occur in the basin: Ancient metamorphic and igneous rocks, which form the highlands around the basin and underlie younger materials in the foothills and lowlands; younger sedimentary and volcanic rocks, which contain the principal aquifers and accumulated as a filling in an ancient broad valley that had been eroded into the older rocks.

The oldest water-bearing materials consist of products derived by weathering from the older crystalline rocks. In part these materials have remained in place as a mantle over the rock, but in part they have been reworked, sorted, and transported to the lower slopes and the valley floor. Intermittently and over a long period of time basaltic lava, named the Columbia River basalt, flowed eastward and inundated the ancient lowland of the Moscow basin. This same lava formed the Columbia Plateau. Erosion of the older granitic and metamorphic rocks in the surrounding hills and mountains continued during the volcanic period, and the materials derived from them were deposited along streams and in lakes around the margins of the basin between periods of lava extrusion. Thus the filling in the ancestral Moscow basin consists of alternating layers of sedimentary material and basaltic lava (figs. 28, 29). The sedimentary deposits interfingering with the Columbia River basalt were named the Latah formation by Pardee and Bryan (1926) for exposures along Latah Creek south of Spokane.

During the transportation and deposition of the sedimentary material, the coarser deposits accumulated nearest the source on the sloping sides of the valley, so that today some of them crop out above the level of highest lava flows and thus are important in the catchment of precipitation. Although the interfingering mantle and sedimentary deposits do not form a continuous layer, and not all are permeable, there are lenses and stringers of permeable sand and gravel that serve both as aquifers and as conduits through which water can percolate from the surface to the deeper aquifers. 


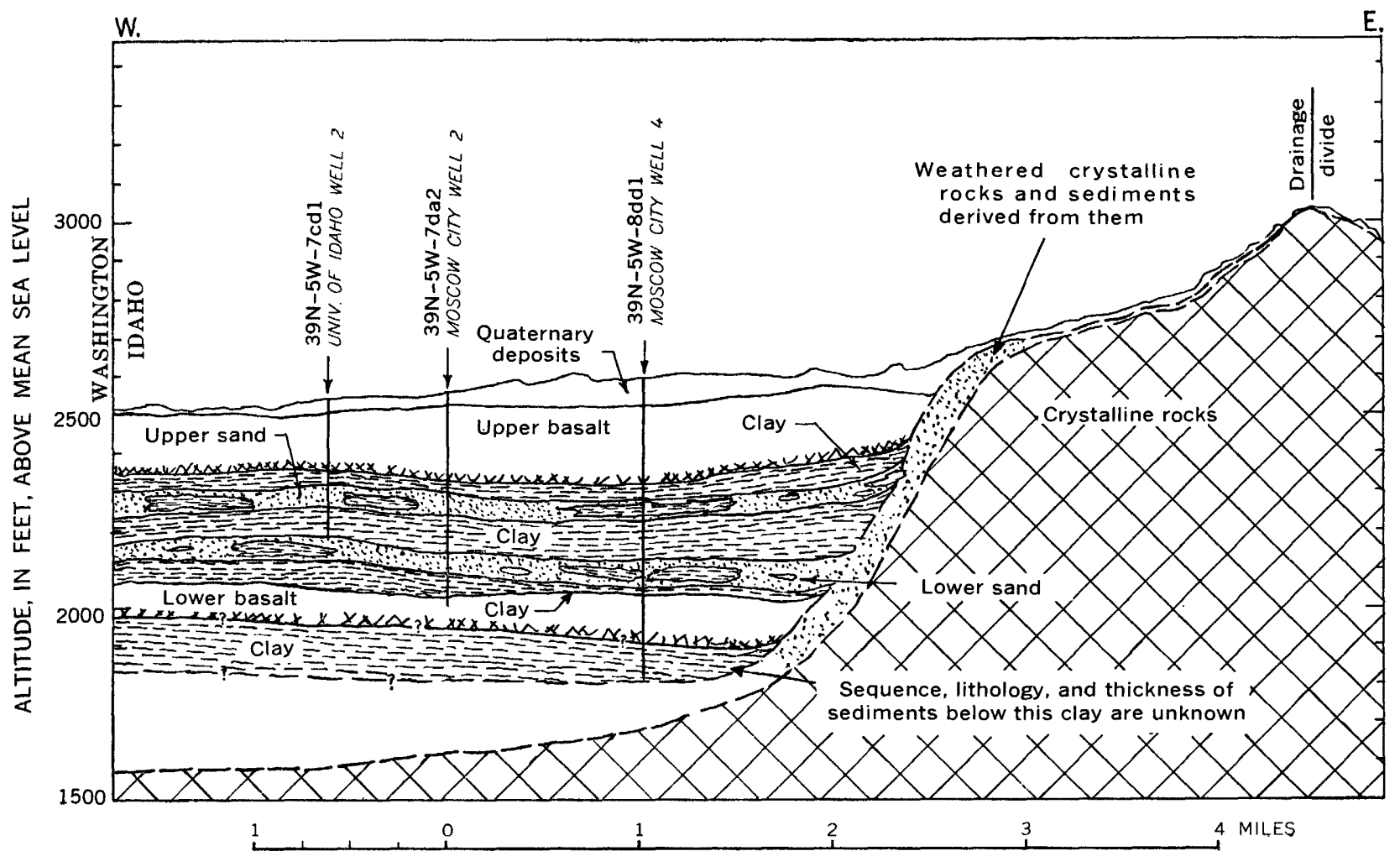

VERTICAL EXAGGERATION APPROXIMATELY $\times 10.5$

FIGURE 28.-Hypothetical east-west section through Moscow basin. 


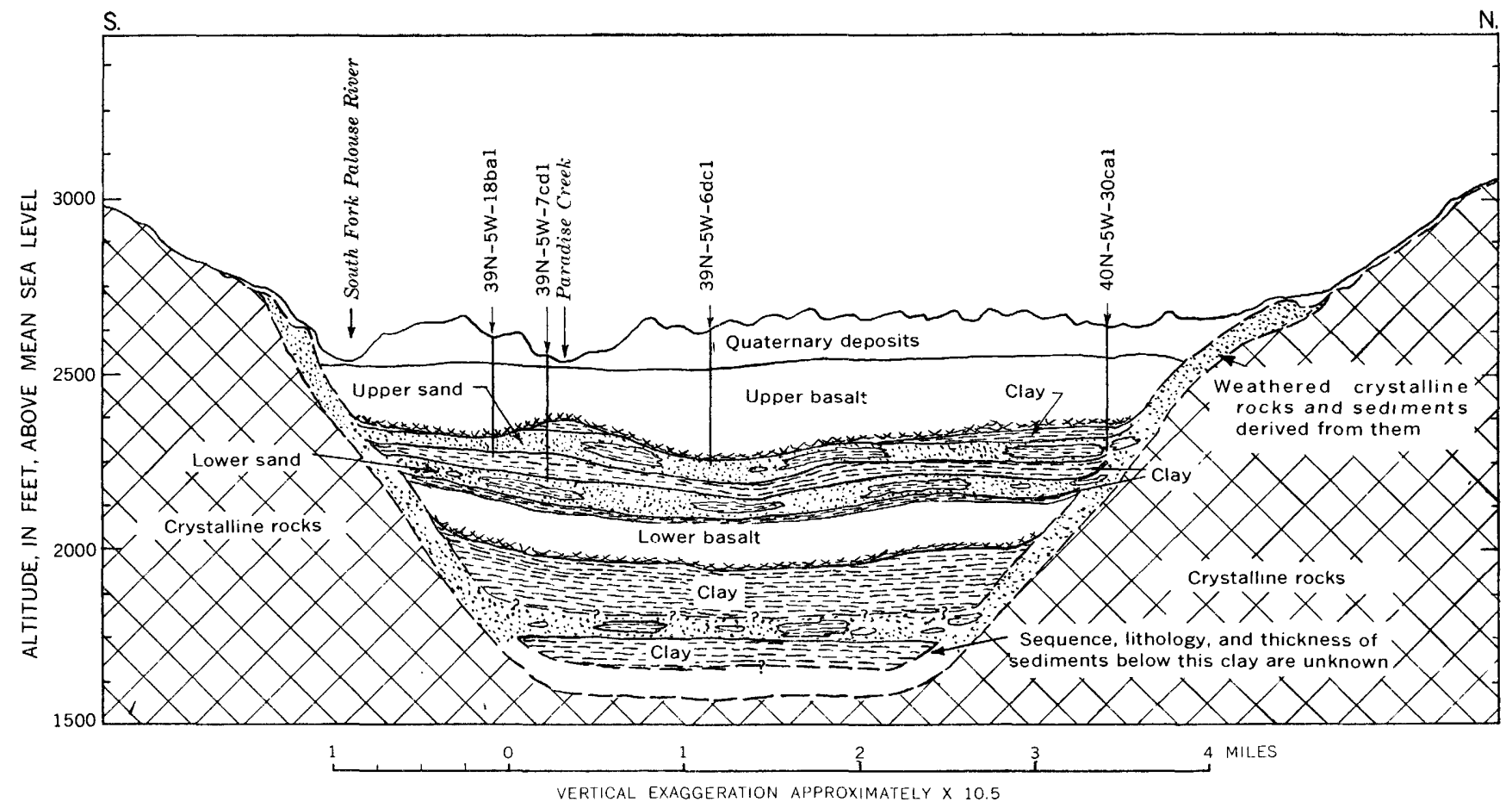

Figure 29.-Hypothetical north-south section through Moscow basin. 
Only minor erosion of the last volcanic flows took place before windborne silt and sand, the Palouse formation, accumulated as a mantle over the basin and lower hill slopes during the Pleistocene epoch (ice age). Locally, streams reworked part of the windborne material and redeposited it, mixed with alluvium from other sources. The present streams have cut a fairly well integrated drainage system, but the rolling topography was formed chiefly during deposition of the Palouse formation.

The weathered granitic and metamorphic rocks and the sediments derived from them crop out in the foothills and on the flanks of the mountains and are believed to be present beneath the Palouse formation around the edge of the highlands. Where exposed in the foothills these materials range in thickness from less than 1 foot to more than 20 feet.

The metamorphic and granitic rocks generally have a low permeability. Water moves principally along joints and other fractures, mostly within a few score feet beneath the surface.

\section{ARTESIAN AQUIFERS}

The Latah formation and two or more flows of the Columbia River basalt of Miocene age are sources of artesian water in the Moscow basin. For convenience the two basalt flows are called the upper and the lower basalt, and the water-bearing sand units of the Latah formation are called the upper and the lower sand. Figure 30 is a detailed stratigraphic section of the Moscow basin. In the Moscow basin the Latah formation and intercalated flows of the Columbia River basalt overlie the weathered crystalline rock, and outside the catchment and recharge area (pl. 13) they underlie the surficial deposits.

\section{UNCONFINED AQUIFERS}

Windblown silt; silty sand and clay composing the Palouse formation; and alluvial silt, sand, gravel, and clay form the surficial deposits in the Moscow basin. The Palouse formation is more than 150 feet thick in parts of the Palouse Hills and forms a thin veneer over most of the higher parts of the area. At other places it has been removed by erosion. Alluvial deposits are found along some streams. Ground water occurs under water-table (including perched) conditions in these sediments. (Perched ground water is unconfined ground water which is held above the main water table by a layer of relatively impermeable rock.) Outside the catchment and recharge area, unconfined ground water is separated from the artesian aquifers by nearly impermeable clay beds and basalt flows (figs. 28, 29 ), which restrict the vertical movement of ground water. 


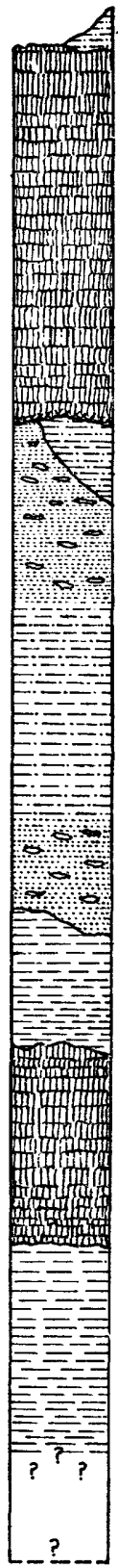

Clay and sandy clay, yellow and brown, micaceous; plant remains common, distribution irregular: thickness variable but less than $100 \mathrm{ft}$.

8asalt, dark-gray to black, dense, very fine grained to glassy: generally ranges from 155 to $225 \mathrm{ft}$ in thickness; nearly impermeable and restricts vertical movement of ground water; fractured zone near base contains ground water under artesian pressure and is aquifer in city wells 2,6 , and 7 . Upper basalt (Columbia River basalt) of figs. 28 and 29.

Clay and sandy clay, gray, micaceous; absent in some places, ranges in thickness from 0 to $80 \mathrm{ft}$; low permeability restricts movement of ground water.

Sand, light-gray; very coarse to very fine quartz and abundant mica; poorly sorted, unconsolidated; lenses of sandy clay common; ranges in thickness from 25 to $70 \mathrm{ft}$; contains ground water under artesian pressure. Upper sand (Latah formation) of figs. 28 and 29 .

Clay, brown and gray, micaceous, sandy; plant remains common; ranges in thickness from 80 to $110 \mathrm{ft}$; low permeability restricts movement of ground water.

Sand, light-gray; very coarse to very fine quartz and abundant mica; poorly sorted, unconsolidated; lenses of sandy clay common; ranges in thickness from 40 to $70 \mathrm{ft}$; contains ground water under artesian pressure. Lower sand (Latah formation) of figs. 28 and 29.

Clay, brown and gray, micaceous, ranges in thickness from 37 to $91 \mathrm{ft}$; low permeability restricts movement of ground water.

Basalt, dark-gray to black, dense, very fine grained to glassy; $100 \mathrm{ft}$ thick in Moscow city well 4; low permeability restricts movement of ground water. Lower basalt (Columbia River basalt) of figs. 28 and 29.

Clay and sandy clay, brown and gray, micaceous; thickness unknown, but $95 \mathrm{ft}$ is penetrated in Moscow city well 4; low permeability restricts movement of ground water. Lithology and thickness of the Latah formation beneath this clay is not known.

FigrRe 30.-Conposite stratigraphic section of the Latah formation and intercalated Columbia River basalt. (Lithologic description based on examination of drill cuttings.) 


\section{WATER RESOURCES}

Part of the precipitation in the Moscow basin is carried off by streams, part is dissipated by evaporation and transpiration, and the remainder percolates downward into the ground and eventually reaches the water table, the upper surface of the zone of saturation.

The base flow of most streams is maintained by the discharge from the zone of saturation in the form of springs and seeps, which occur where the water table intersects the land surface. However, streams may contribute to ground water where they flow over permeable material that lies above the water table. Streams in the Moscow basin both gain water from unconfined aquifers in some places and lose it to them in others. Within the area of artesian recharge, however, the streams contribute to the ground water; the artesian aquifers are not known to contribute water directly to any stream.

\section{SURFACE WATER}

No systematic areal studies have been made of the discharge of streams in the Moscow basin, but discharge records and information on the suspended-sediment load are available for the South Fork of the Palouse River upstream from its junction with Paradise Creek near Pullman, Wash. The following table summarizes these records

Mean daily discharge (monthly average) and suspended sediment load of South Fork Palouse River, Pullman, Wash., 1934-40. Drainage area 81.1 square miles.

[From U.S. Geological Survey, 1936-41. Quantities rounded to 3 significant figures]

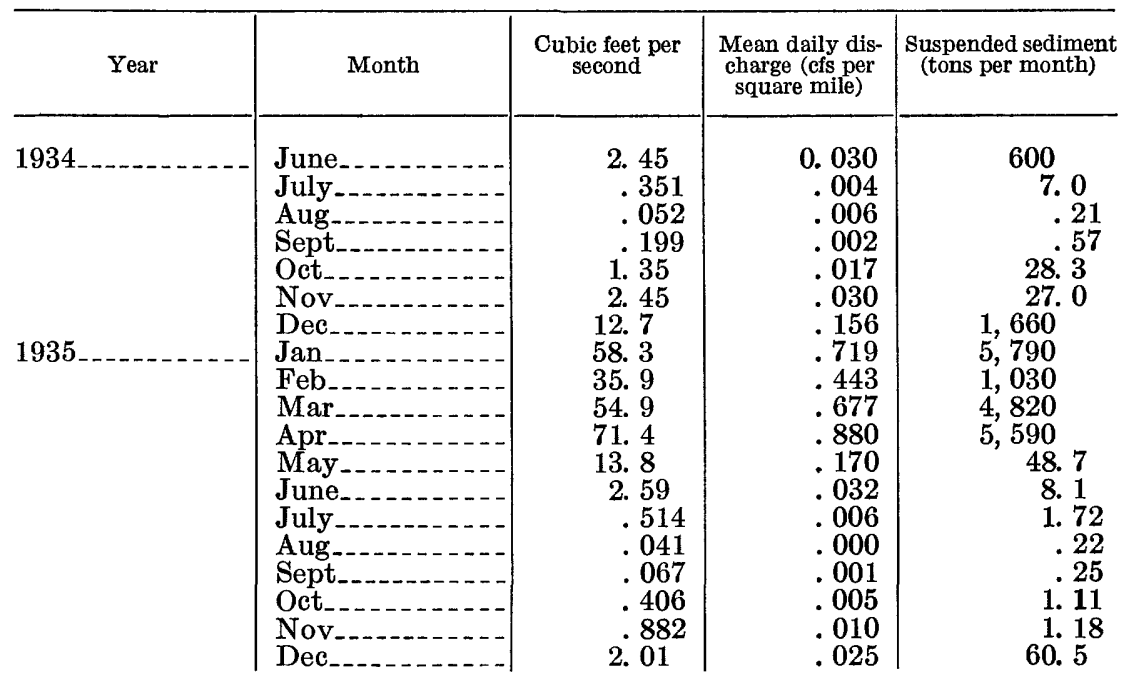


Mean daily discharge (monthly average) and suspended sediment load of South Fork Palouse River, Pullman, Wash., 1934-40. Drainage area 81.1 square miles.-Continued

[From U.S. Geological Survey, 1936-41. Quantities rounded to 3 significant figures]

\begin{tabular}{|c|c|c|c|c|}
\hline Year & Month & $\begin{array}{l}\text { Cubic feet per } \\
\text { second }\end{array}$ & $\begin{array}{l}\text { Mean daily dis- } \\
\text { charge (cfs per } \\
\text { square mile) }\end{array}$ & $\begin{array}{l}\text { Suspended sediment } \\
\text { (tons per month) }\end{array}$ \\
\hline \multirow[t]{12}{*}{1936} & Jan_... & 29.4 & 0.362 & 6,600 \\
\hline & Feb & 32.1 & .396 & 8,810 \\
\hline & Mar.-. & 85. 9 & 1.06 & 18,900 \\
\hline & Apr & 26.8 & .330 & 675 \\
\hline & May_- & 8. 84 & .109 & 1,450 \\
\hline & June _. & 1. 67 & .020 & 11. 5 \\
\hline & July_-- & .152 & .002 & 1.03 \\
\hline & Aug & 0 & 0 & 0 \\
\hline & Sept_... & .016 & .000 & .06 \\
\hline & Oct... & .187 & .002 & 1. 42 \\
\hline & Nov_-- & .330 & .004 & 1. 77 \\
\hline & Dec & .927 & .011 & 3.26 \\
\hline \multirow{11}{*}{$1937 \ldots \ldots \ldots$} & $\operatorname{Jan}_{-\ldots}$ & .506 & .006 & 1. 37 \\
\hline & Feb_-- & 6. 90 & $\stackrel{085}{.087}$ & 14. $900^{93.4}$ \\
\hline & Apr.- & $\begin{array}{r}105 \\
77.6\end{array}$ & .957 & 11,200 \\
\hline & May -- & 10.7 & .132 & 51.1 \\
\hline & June... & 3. 71 & .46 & 347 \\
\hline & July_-_ & .394 & .005 & 4. 47 \\
\hline & Aug - - & .0004 & .000 & .00 \\
\hline & Sept_. . & .034 & .000 & .07 \\
\hline & Oct_-- & .637 & .008 & 2.84 \\
\hline & Nov_-- & 1. 73 & .021 & $\begin{array}{r}31.2 \\
632\end{array}$ \\
\hline & Dec $\ldots$ & 8. 23 & .101 & $\begin{array}{r}632 \\
3.110\end{array}$ \\
\hline \multirow[t]{12}{*}{1938} & Jan.... & 27. 9 & .344 & 3,110 \\
\hline & Feb_... & 48. 6 & .599 & 1,970 \\
\hline & Mar & 85.1 & 1.05 & 5,730 \\
\hline & Apr & 36.5 & .450 & 890 \\
\hline & May_- & 8. 60 & .106 & 47.1 \\
\hline & June & 1. 68 & .021 & 9.68 \\
\hline & July_--_- & .357 & .004 & 1. 37 \\
\hline & Aug--- & 0 & & \\
\hline & Sept..... & 0 & & 0 \\
\hline & Oct... & 1.08 & .013 & 2. 76 \\
\hline & Nov_.-- & 1. 11 & .014 & 8. 27 \\
\hline & Dec & 1.65 & .020 & 33. 0 \\
\hline \multirow[t]{11}{*}{1939} & Jan & 3. 11 & .038 & 62.2 \\
\hline & Feb_.... & 25.5 & .314 & 3,100 \\
\hline & Mar.... & 133 & 1. 64 & 25,400 \\
\hline & Apr $\ldots$ & 19.8 & .244 & 185 \\
\hline & May_..._... & 4. 12 & .051 & 20.7 \\
\hline & June_.......... & 1. 03 & .013 & 2.76 \\
\hline & July_........ & $0^{.186}$ & $0^{.002}$ & $0^{.70}$ \\
\hline & $\begin{array}{l}\text { Aug } \\
\text { Sept }\end{array}$ & $\begin{array}{l}0 \\
0\end{array}$ & $\begin{array}{l}0 \\
0\end{array}$ & $\begin{array}{l}0 \\
0\end{array}$ \\
\hline & Oct. & .097 & .001 & .000 \\
\hline & Nov & .371 & .004 & .000 \\
\hline & Dec_._... & .971 & .012 & 4. 29 \\
\hline \multirow[t]{6}{*}{1940} & Jan_.......... & 3.23 & .040 & 52.8 \\
\hline & Feb_-_. & 48. 4 & .597 & 10,900 \\
\hline & Mar......... & 54. 3 & .670 & 7,610 \\
\hline & Apr & 25.9 & .319 & 1,910 \\
\hline & May_.......... & 4. 33 & .053 & 37.1 \\
\hline & June & .503 & .006 & 2. 30 \\
\hline
\end{tabular}


for the period June 1934 through June 1940. There is a wide yearly variation in the mean daily discharge of the South Fork, the low usually occurring during August and the high during March.

The estimated average annual runoff from the Moscow basin, based on incomplete records of streamflow and precipitation, is about 12,000 acre-feet. To estimate the runoff, it was assumed that the ratio of runoff to precipitation per unit area throughout the Moscow basin is the same as the ratio for the South Fork of the Palouse River above Pullman, Wash., and that precipitation throughout the area is the same as at Moscow. The estimate of the amount of surface runoff is probably low, as it does not include the higher runoff of the highland area, where slopes are steep, soil cover is thin, and precipitation is higher than at Moscow.

\section{GROUND WATER}

Ground water occurs under water-table (unconfined) conditions in the unconsolidated surficial sediments and under artesian conditions in the sand layers of the Latah formation, and in fractured zones in the Columbia River basalt.

\section{UNCONEINED WATER}

In the Moscow basin the unconsolidated Pleistocene sediments and, in places, the upper part of the upper basalt, yield sufficient unconfined water to wells for rural, domestic, and stock use. Possibly enough water could be pumped locally from these aquifers to supply small industries, but no large withdrawals can be made. These aquifers yield less than 1,000 gallons a day to the average wells.

The depth to the water table depends partly on the topography and the lithology and structure of the rocks, and partly on the local recharge and discharge. On the flanks of the basin and on higher parts of the Palouse Hills, the depth to water exceeds 200 feet, as in well $39 \mathrm{~N}-5 \mathrm{~W}-5 \mathrm{bb} 1$ in which the water table is reported to be only a few feet above the surface of the basalt that underlies the Palouse formation. Near the center of the basin the water table is at a shallow depth. The unconsolidated Pleistocene sediments of the Moscow basin contain perched ground-water bodies of limited areal extent, but these are not important even for limited domestic and stock use.

Water in the unconfined aquifers moves away from the drainage divides toward the axis of the valley, and thence westward into Washington. The yearly range of fluctuation of the water table is generally from 4 to 6 feet; its depth below the surface is lowest in November or December and highest usually in April (fig. 31). 


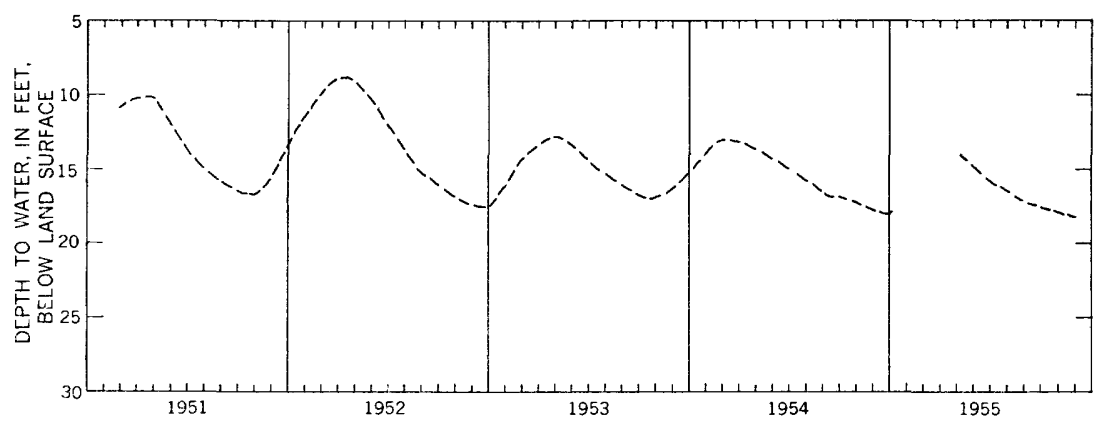

FigURe 31,-Hydrograph of well $39 \mathrm{~N}-5 \mathrm{~W}-10 \mathrm{ac1}$.

\section{ARTESIAN WATER}

Sand beds in the Latah formation and a permeable zone near the base of the upper basalt are the artesian aquifers tapped by wells of the city of Moscow, the University of Idaho, and the Sunset Memorial Gardens cemetery. The artesian water is replenished by precipitation on the catchment and recharge area (pl. 13), which covers about 32.4 square miles (20,800 acres). The boundary between the catchment and recharge area and the remainder of the basin represents the approximate location of the contact between the nearly impervious clay beds of the Latah formation, which restrict the vertical movement of ground water, and the interfingering mantle and sedimentary deposits, which serve as aquifers and conduits through which water can move from the surface to the lower aquifers. Water enters the artesian reservoir by percolating downward through the surficial materials and then moves laterally in the sand and gravel beds of the Latah formation and the permeable zones in the basalt. In places, impermeable dense basalt and fine-grained sediments impede vertical movement of the ground water and confine it under artesian pressure. Formerly, when artesian pressures were higher, artesian water not recovered by pumping moved westward out of Idaho. Increased withdrawals, however, have restricted, and possibly have halted, this westward movement.

\section{WATER LEVELS}

Records and reliable oral reports on water levels in wells tapping the artesian aquifers show that the altitude of the piezometric (pressure-head-indicating) surface has been declining for more than 60 years. Laney and others (1923, p. 6) state: "It is established from various sources and beyond reasonable doubt that flowing artesian wells existed in Moscow in 1890 to 1895." The static water level in city well 1 (39N-5W-7da3) was near the ground surface in 1895; the depth to the static water level was about 44 feet in 1923,65 feet 
in 1947 , and 94 feet in 1955 . Thus, in the first 28 years of record the static water level in this well declined an average of 1.6 feet per year; the average annual decline decreased to 0.85 foot in the following 24 years, and then increased to 3.6 feet per year in the period 1947-55.

Depth-to-water measurements in well $39 \mathrm{~N}-5 \mathrm{~W}-7 \mathrm{dd} 1$ show that the static water level declined about 18 feet between February 1951 and November 1955 (fig. 32). The rate of decline was about 4 feet per year except in 1952, when it was about 1 foot. The records indicate that the decline of the piezometric surface has greatly accelerated since 1954, probably owing to increased withdrawals of water from wells.

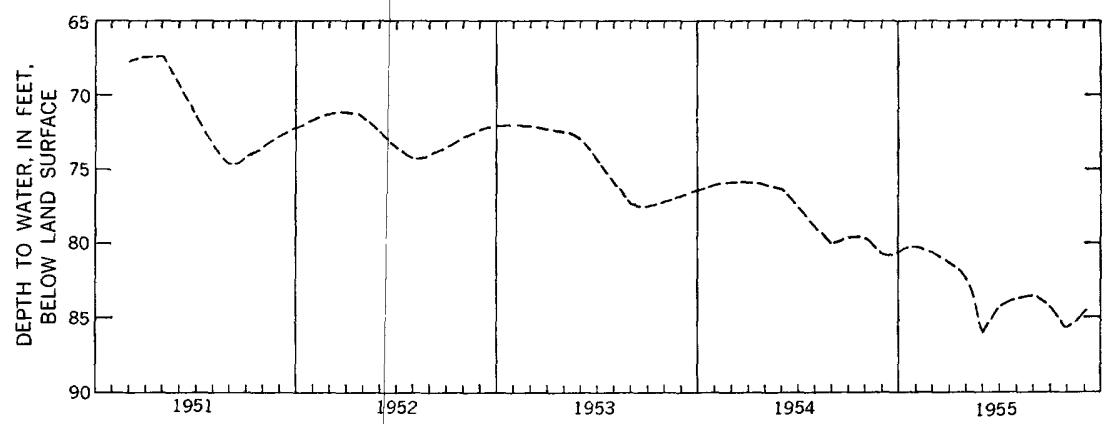

FiguRE 32.-Hydrograph of well 39N-5W-7dd1.

The annual cycle of water-level fluctuations apparently is related chiefly to pumping. The high occurs during the period of minimum withdrawals in March or April and the low during the period of maximum withdrawals in July or August. Comparison of the hydrograph with monthly precipitation shows that the annual high water level also coincides with the end of the period of maximum rainfall and surface runoff, and that the low occurs near the end of the annual period of minimum rainfall. The hydrograph shows also that recovery of the static water level never is complete, for the highest altitude of the piezometric surface in each succeeding year is lower than that of the previous year.

\section{PRECIPITATION}

On the basis of a normal annual precipitation of 21.7 inches, the average yearly volume of precipitation on the Moscow basin is estimated at 71,000 acre-feet. Assuming that the normal annual precipitation on the catchment and recharge area is 22 inches, the volume falling on that area is 38,000 acre-feet.

\section{EVAPOTRANSPIRATION}

Criddle (1947, p. 3, table 1) estimated that consumptive use of irrigation water by small-grain crops, not including precipitation 
consumed during the crop-growing period, is 0.83 acre-foot per acre in the vicinity of Lewiston and the Spokane River. Applying that estimate to the Moscow area, and adding 0.61 foot of precipitation that presumably is used during the growing period, the estimated seasonal evapotranspiration at Moscow is 1.44 acre-foot per acre. Glenn M. Horner (written communication, Oct. 24, 1955) reports that, when the moisture in the upper 6 feet of the soil is at field capacity on April 1, evapotranspiration from Palouse soil during the growing season is 8.6 inches ( 0.72 acre-foot per acre) on wheatland and 10.3 inches (0.86 acre-foot per acre) on grassland, plus the amount of precipitation. When the soil-moisture content on April 1 is less than the field capacity, evapotranspiration during the year is less. Therefore, the estimated total evapotranspiration from soil moisture and precipitation on wheatland during a growing season beginning with the soil at field capacity is about 1.33 acre-foot per acre and that on grassland about 1.47 acre-foot per acre. Those amounts are quite close to estimates of evapotransporation in adjacent areas (Simons, 1953, p. 22). They do not include evapotranspiration during the nongrowing season, which is believed to be low.

Evapotranspiration from the forested area of the Moscow drainage basin is not known, but it is thought to be slightly less than that from the grassland. For the purpose of this report the evapotranspiration is assumed to be 1.4 acre-foot per acre yearly. All these assumed figures are rough estimates and indicate only the order of magnitude; they may be in error by 25 percent.

The estimates of evapotranspiration neglect two unknown factors: loss of precipitation by interception and by sublimation of snow and ice. Part of the precipitation is intercepted by the vegetal canopy before reaching the ground and is returned to the atmosphere by evaporation and sublimation. This permanent loss of precipitation, called interception loss, warrants careful consideration. In areas where interception loss has been determined, conservative values usually range from 15 to 30 percent of the total winter precipitation and from 20 to 40 percent of the summer precipitation, depending on the type and density of vegetal cover and the type, magnitude, intensity, and frequency of storms (U.S. Corps of Engineers, 1956, p. 89). Interception-loss percentages for areas similar to the Moscow basin in vegetation and climate are not available. Also, the available data do not permit estimates of precipitation losses due to sublimation.

\section{RUNOFF AND RECHARGE}

The assumed average annual rates of evapotranspiration are about 29,000 acre-feet from the catchment and recharge area and 26,000 acre-feet from the remainder of the basin, or 55,000 acre-feet, plus 
or minus 15,000 acre-feet from the whole basin. The assumed yearly runoff from the basin is about 12,000 acre-feet, of which half is from the catchment and recharge area. The amount of precipitation on the basin, less runoff and evapotranspiration, that is apparently available for ground-water recharge is about 4,000 acre-feet. However, a quantity of 4,000 acre-feet is within the limits of error of the estimates of evapotranspiration.

Meaningful quantitative estimates of ground-water recharge obviously cannot be based on the relation of estimated precipitation to evapotranspiration. On the basis of available data it can be concluded only that the recharge must be less than the discharge through the wells $(2,200$ acre-feet annually), plus the natural discharge from springs and seeps (unknown), plus any remaining underflow out of the basin (unknown), as shown by the progressive decline in water levels in wells in the period of record.

Although the amount of recharge cannot be determined directly, it can be found indirectly by determining the amount of discharge and changes in storage. Ground-water discharge from the basin consists of artificial withdrawals, which can be determined quite closely if accurate pumping records are maintained, and natural discharge. Natural discharge from the unconfined aquifers, in addition to the effluent flow which helps maintain the base flow of streams, consists of underflow out of the basin. Natural discharge from artesian aquifers in the Moscow basin consists entirely of underflow out of the basin and can be estimated provided the coefficient of transmissibility, the hydraulic gradient, and the cross-sectional area are known. These factors cannot be evaluated on the basis of data now available. Additional wells would be required for determining the cross-sectional area of the aquifers and the hydraulic gradient, and pumping tests would be required for determining the coefficients of transmissibility and storage.

\section{CHEMICAL QUALITY OF THE WATER}

Chemical analyses of water from the city, university, and other wells in the Moscow basin are shown in the following table. The quality of the water sampled from artesian aquifers is very similar to the quality of water from unconfined aquifers. The water is of the calcium bicarbonate type: It is moderately hard and contains relatively large amounts of iron and silica. Reduction of the hardness and iron content of the municipal water supply would make the water more suitable for municipal, domestic, and industrial use.

No chemical analyses of surface water from the basin are available, but the hardness and iron content probably are less than those 
Chemical analyses, in parts per million, of water from the Moscow basin

\begin{tabular}{|c|c|c|c|c|c|c|c|c|c|c|c|c|c|c|c|c|c|c|}
\hline \multirow{2}{*}{ Well } & \multirow[b]{2}{*}{$\begin{array}{l}\text { Date of } \\
\text { collection }\end{array}$} & \multirow{2}{*}{$\begin{array}{l}\text { Tem- } \\
\text { pera- } \\
\text { ture } \\
\left({ }^{\circ} \mathrm{F}\right)\end{array}$} & \multirow{2}{*}{$\begin{array}{r}\text { Silica } \\
\left(\mathrm{SiO}^{2}\right)\end{array}$} & \multirow[b]{2}{*}{$\begin{array}{l}\text { Iron } \\
(\mathrm{Fe})\end{array}$} & \multirow{2}{*}{$\begin{array}{l}\text { Cal- } \\
\text { cium } \\
\text { (Ca) }\end{array}$} & \multirow{2}{*}{$\begin{array}{c}\text { Mag- } \\
\text { ne- } \\
\text { sium } \\
(\mathrm{Mg})\end{array}$} & \multirow{2}{*}{$\begin{array}{l}\text { So- } \\
\text { dium } \\
(\mathrm{Na})\end{array}$} & \multirow{2}{*}{$\begin{array}{l}\text { Potas- } \\
\text { sium } \\
(\mathrm{K})\end{array}$} & \multirow{2}{*}{$\begin{array}{c}\text { Bicar- } \\
\text { bonate } \\
\left(\mathrm{HCO}_{3}\right)\end{array}$} & \multirow{2}{*}{$\begin{array}{c}\text { Sul- } \\
\text { fate } \\
\left(\mathrm{SO}_{4}\right)\end{array}$} & \multirow{2}{*}{$\begin{array}{l}\text { Chlo- } \\
\text { ride } \\
\text { (Cl) }\end{array}$} & \multirow{2}{*}{$\begin{array}{l}\text { Fluo- } \\
\text { ride } \\
\text { (F) }\end{array}$} & \multirow{2}{*}{$\begin{array}{c}\mathrm{Ni}- \\
\text { trate } \\
\left(\mathrm{NO}_{3}\right)\end{array}$} & \multirow{2}{*}{$\begin{array}{l}\text { Dis- } \\
\text { solved } \\
\text { solids }\end{array}$} & \multicolumn{2}{|c|}{$\begin{array}{c}\text { Hardness as } \\
\mathrm{CaCO}_{3}\end{array}$} & \multirow{2}{*}{$\begin{array}{c}\text { Specific } \\
\text { conduct- } \\
\text { ance } \\
\text { (micro- } \\
\text { mhos } \\
\text { at } 25^{\circ} \\
\text { C) }\end{array}$} & \multirow{2}{*}{$\mathrm{pH}$} \\
\hline & & & & & & & & & & & & & & & $\begin{array}{c}\text { Car- } \\
\text { bonate }\end{array}$ & $\mid \begin{array}{c}\text { Non- } \\
\text { car- } \\
\text { bon- } \\
\text { ate }\end{array}$ & & \\
\hline $\begin{array}{r}39 \mathrm{~N}-5 \mathrm{~W}-7 \mathrm{aa1} \\
\text { 7cd1 } \\
\text { 7cd1 } \\
\text { 7da2 } \\
\text { 7da2 } \\
\text { 7da3 } \\
\text { 8ab1 } \\
\text { 8ab1 } \\
\text { 8ab2 } \\
\text { 8ab2 } \\
\text { 8ab2 } \\
\text { 8sb2 } 1 \\
18 \mathrm{ba1} 1\end{array}$ & $\begin{array}{r}5-22-46 \\
11-20-53 \\
3-29-55 \\
3-29-55 \\
5-22-46 \\
5-22-46 \\
2-26-51 \\
1-4-52 \\
5-22-46 \\
1-4-52 \\
3-29-55 \\
9-29-55 \\
3-29-55\end{array}$ & $\begin{array}{c}54 \\
---- \\
---- \\
-\overline{54} \\
54 \\
51 \\
54 \\
54 \\
54 \\
-54 \\
----\end{array}$ & $\begin{array}{c}-\overline{62} \\
---- \\
---- \\
---- \\
5 \overline{7} \\
---- \\
---- \\
--- \\
5 \overline{5} \\
----\end{array}$ & $\begin{array}{l}2.0 \\
2.2 \\
1.4 \\
1.3 \\
6.5 \\
2.0 \\
1.2 \\
.95 \\
6.5 \\
.95 \\
.67 \\
.26 \\
1.9\end{array}$ & $\begin{array}{c}30 \\
33 \\
--- \\
-30 \\
30 \\
35 \\
33 \\
30 \\
33 \\
-\overline{27} \\
---\end{array}$ & $\begin{array}{c}11 \\
14 \\
-\cdots \\
-11 \\
11 \\
12 \\
12 \\
11 \\
12 \\
-10 \\
----\end{array}$ & $\begin{array}{c}---- \\
---- \\
---- \\
---- \\
---- \\
---\overline{1} \\
---- \\
---- \\
---- \\
-13 \\
---\end{array}$ & 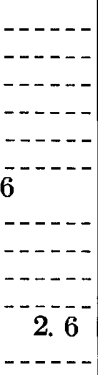 & $\begin{array}{l}161 \\
166 \\
165 \\
166 \\
134 \\
132 \\
171 \\
171 \\
163 \\
140 \\
153 \\
160 \\
166\end{array}$ & $\begin{array}{c}15 \\
18 \\
---- \\
-17 \\
15 \\
25 \\
22 \\
17 \\
22 \\
4 \\
11 \\
---\end{array}$ & $\begin{array}{c}2 \\
7 \\
2 \\
3 \\
1 \\
2 \\
3 \\
4 \\
1 \\
4 \\
-2 \\
2 \\
8\end{array}$ & $\begin{array}{c}0.3 \\
.4 \\
---- \\
---- \\
.4 \\
.3 \\
.3 \\
.4 \\
.4 \\
.4 \\
-0- \\
.0 \\
-\cdots-\end{array}$ & 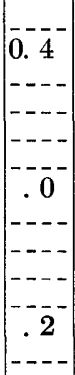 & $\begin{array}{c}232 \\
260 \\
-356 \\
-240 \\
--\overline{256} \\
-200 \\
-\end{array}$ & $\begin{array}{l}120 \\
140 \\
108 \\
116 \\
120 \\
120 \\
137 \\
132 \\
120 \\
132 \\
116 \\
110 \\
184\end{array}$ & \begin{tabular}{c}
---- \\
---- \\
---- \\
---- \\
---- \\
$--\overline{0}$ \\
---- \\
---- \\
--- \\
\hdashline 0 \\
---
\end{tabular} & 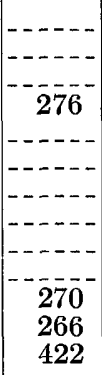 & $\begin{array}{l}7.2 \\
6.7 \\
8.1 \\
7.2 \\
6.6 \\
7.2 \\
7.2 \\
6.9 \\
6.6 \\
6.9 \\
7.6 \\
7.2 \\
8.1\end{array}$ \\
\hline
\end{tabular}

${ }^{1}$ Analysis by U.S. Geological Survey. 
of the ground water. Addition of surface water to the municipal system probably would improve the chemical quality of the supply.

The chemical quality of ground water is related to the geology of the area in which the water occurs. Water moving over or through rocks dissolves some of their mineral constituents. In a small area, such as the Moscow basin, in which the rocks are fairly uniform in mineral composition, the chemical quality of the water probably does not vary much from place to place.

Recently the iron content of the municipal supply reportedly increased from about $2 \mathrm{ppm}$ to as much as $25 \mathrm{ppm}$. Investigations of the cause of this increase in iron content are now in progress by the Idaho State Department of Public Health, Division of Laboratories (Vaughn Anderson, written communication, Jan. 1956).

Data regarding the chemical quality of surface water in the Moscow basin is necessary in planning for the use of surface water as a supplemental source. Available data indicate a large seasonal fluctuation in the volume of water in streams in the Moscow basin, and there may be a considerable change in the chemical quality of surface water between periods of high and low flow. Systematic sampling and analysis of samples would be required to determine the chemical characteristics of the surface water.

\section{WATER OUTLOOK}

\section{FUTURE DEMAND}

The population of Moscow, including students attending the University of Idaho, increased about 26 percent from 1940 to 1950 (from 8,423 to 10,593 ). The estimated population in 1955 was 12,000 , or 13.3 percent more than in 1950 , the year of the last official census (Everett Will, Mayor of Moscow, oral communication, 1955). Assuming continued growth at about the same rate, the population will be 13,250 in 1960 and 16,500 in 1970 . In 1955 the city and university used about 720 million gallons (2,200 acre-feet) of artesian waterslightly less than 60,000 gallons per capita per year, or slightly more than 160 gallons per capita per day. At that rate, consumption would be nearly 800 million gallons of water in 1960 and nearly 1 billion gallons in 1970 . These estimates probably are conservative because more water would have been used in 1955 if use had not been restricted. If, as city officials seem to hope, the economy becomes diversified by an influx of industrial establishments, an increase must be made in the amount of water available to the municipal system. The means of supplementing the water supply are a major concern of the city. Assuming moderate industrial development within the city and accelerated population growth incident to industrial growth 
in the city and in the basin, the water demand may be about 1.1 billion gallons in 1960 and 1.5 billion gallons in 1970 .

The amount of water withdrawn from the artesian aquifers by municipal wells in 1955 plus the amount moving through and out of the basin (natural discharge) exceeded the estimated average annual increment, as shown by the record of declining artesian pressure, a decline which has accelerated during the past few years in the Moscow area. Water for this resulting deficiency was obtained from ground water in storage. Water levels will continue to decline as long as the withdrawal exceeds the portion of the annual increment than can be intercepted before it leaves the basin or is discharged naturally.

Water levels in artesian wells have not yet declined to the level of the stratigraphically highest artesian aquifer. Therefore, no aquifer in the pumped area has been dewatered. However, dewatering must have occurred upgradient in the aquifers, because the artesian pressure has been lowered.

\section{SUPPLEMENTARY SOURCES}

Declining artesian pressure will cause a progressive increase in pumping lifts and may require deepening existing wells or drilling additional wells. This would supply needed water, at least temporarily, but would not solve the problem of a deficient supply. The obvious and ultimate requirement is to obtain an additional source of water or to increase the yield of the present source.

\section{GROUND WATER}

Some wells in the Moscow basin obtain unconfined water, but all those wells are small in diameter and each has a reported capacity of less than $100 \mathrm{gpm}$ (gallons per minute). The aquifer might yield water at moderate rates to large-diameter wells at some places, but large supplies could not be obtained except by using several wells spaced over a fairly wide area. The unconfined aquifers are not considered to be promising sources of water for public supply in the Moscow area.

Additional artesian water could be obtained from new wells or by heavier pumping of old wells, but heavier pumping might require deepening of the old wells. The existing artesian wells may not intercept all the artesian water, some of which may move westward out of the basin. To intercept as much of the water as possible, new wells would have to be constructed in strategic locations not yet known. However, the accelerated decline in recent years suggests the possibility that the artesian pressure has been lowered to the extent that little or no water now escapes to the west. 


\section{SURFACE WATER}

The estimated average annual surface-water yield of the basin is 12,000 acre-feet (p. 339). However, the amount that could be recovered for municipal use is unknown because estimates of reservoir capacity and of seepage and evaporation losses have not been made. Furthermore, in some years the surface-water yield is much less than average. The largest amount of water for surface storage, of course, would be available in the downstream reaches of streams, where diversion of water from Paradise Creek to the South Fork of the Palouse River is possible. Obviously, a study of surface-water discharge, chemical quality and sediment load of the water, and storage sites would be necessary in planning for surface-water use. Combined use of surface water with ground water might well be programmed to minimize the draft on each, by using surface water in the spring and summer while it is available and ground water in the fall and winter. Lowered draft on the ground water would permit gradual recovery of artesian pressure and thus provide a reserve for periods of deficient precipitation and runoff.

Reliable figures for recharge, natural discharge, and the volume of water taken from storage would permit computation of the perennial yield of the artesian aquifers. Adequate records of surface-water discharge and the chemical quality of the surface water would provide a firm basis for evaluation of the surface-water resources of the basin. Thus, with sufficient data, the total water resources of the basin could be evaluated. This would provide the city with a means of comparing current use with total supply, aid in planning the growth of the city, and permit investigation of the need for supplemental sources of water supply.

\section{ARTIFICIAL RECHARGE OF GROUND WATER}

Part of the estimated 12,000 acre-feet of surface water available annually in the Moscow basin might be used for artificial recharge of the artesian aquifers. Artificial-recharge possibilities under the specific local conditions in the Moscow basin probably merit special study. Several methods of artificial recharge are used effectively: spreading water in infiltration ponds or diked fields underlain by permeable materials which are hydraulically continuous with an aquifer, constructing dams where streams cross aquifer outcrops, and injecting water directly into the aquifer through intake wells or shafts. Injection wells probably would be the most feasible means of recharge in the Moscow basin, but other methods might be feasible locally.

The suspended load of sediment in surface water would be a factor in determining the efficiency of any method of recharge. Clean water 
is desirable for all methods and is generally considered essential for intake wells, because sediment would clog the aquifer around an intake well. A recharge system might include settling basins or other works for clarifying the recharge water. If surface water were to be used part of the time for municipal supply, a treatment plant would be an essential component of the system. At certain times more water might be available than is required for municipal use, and this surplus water, after filtration, could be injected into recharge wells.

The rate of recharge through intake wells in the artesian aquifer would depend upon the hydraulic properties of the aquifer and the efficiency of the wells. In general, water can be injected through a well at about the same rate at which the well can be pumped, assuming a buildup in head comparable to the drawdown during pumping. Probably not all the recharge water could be recovered from the aquifer, because some likely would join-or restore-the natural movement of water out of the basin.

\section{LOGS AND RECORDS OF WELLS}

The well logs in table 1 were obtained from drillers and well owners.

The 40 wells listed in table 2 include wells tapping the confined (artesian) aquifer and the unconfined (water table) aquifer. Wells are used for public, domestic, stock, and industrial supplies. One well (39N-5W-17da1), which supplies water to a cemetery, is used principally for irrigation.

\section{SUMMARY}

Moscow is near the west end of a small westward-facing amphitheaterlike drainage basin having an area of slightly more than 60 square miles. Most of the basin is drained by the South Fork of the Palouse River and Paradise Creek. A small area in the northwest corner of the area is drained by Missouri Flat Creek.

Crystalline rocks crop out in the highlands to the north, east, and south of Moscow and are believed to underlie the entire basin. These rocks are almost impermeable and form a basement floor beneath the water-bearing formations. A weathered mantle, at places reworked and somewhat sorted, consisting of sand, gravel, silt, and clay is older than the Latah formation and overlies the crystalline rocks. These materials form a conduit through which water moves from the surface in the higher areas to the artesian aquifers. Fluviatile and lacustrine clay, silt, and sand compose the Latah formation and overlie the weathered mantle and the crystalline rock. At least 
two flows of the Columbia River basalt are interbedded with the sediments of the Latah formation. Sand beds in the Latah formation and permeable zones in the basalt flows are artesian aquifers and are the source of the public water supply for Moscow and the University of Idaho. Unconsolidated deposits of clay, sand, and loess overlying the Latah formation and Columbia River basalt contain unconfined water.

In 1955 Moscow and the University of Idaho wells pumped about 720 million gallons (about 2,200 acre-feet) of water from the artesian aquifers. Continued decline of water levels in the artesian wells indicates that withdrawal plus the natural discharge from the artesian aquifers exceeds the yearly increment. Future water needs of Moscow and the University of Idaho may be on the order of 1.1 billion gallons (about 3,400 acre-feet) by 1960 and 1.5 billion gallons $(4,600$ acre-feet) by 1970 .

Water levels will continue to decline as long as withdrawals exceed the perennial yield of the artesian aquifers. Progressive increase in pumping lifts may eventually necessitate deepening existing wells or drilling new wells. Thus increased, the overdraft on the artesian aquifers would only postpone and make more difficult an ultimate solution to the water-supply problem. The ultimate need is for an additional source of water to be used directly or for artificial recharge to the artesian aquifers.

Available data are insufficient to permit determination of the annual recharge to the artesian aquifers or the perennial yield from them. Recharge cannot be determined directly but can be determined indirectly from the amount of discharge and the changes in storage. Discharge consists of artificial withdrawal, which can be determined quite accurately if adequate records of pumpage are maintained, and natural discharge. Natural discharge in the Moscow basin probably consists entirely of underflow out of the basin and can be estimated if the coefficient of transmissibility, the hydraulic gradient, and the cross-sectional area are known. These factors cannot be evaluated on the basis of data now available. Additional well data would be required for determining the cross-sectional area of the aquifers and the hydraulic gradient; pumping tests would be required for determining the coefficients of transmissibility and storage. These data would be useful also in several other problems. For example, determination of the transmissibility would permit computation of the rate at which injection wells would accept water for artificial recharge of the artesian aquifers. The amount of head loss in existing wells (well loss), and thus the efficiency of the wells, could be determined. (Well loss is the component of drawdown in a pumped well resulting from the turbulent flow of water in the aquifer in the imme- 
diate vicinity of the well, through the well screen, and in the well casing.) Also, the optimum spacing, depth, and construction of wells could be determined.

The estimated average annual surface-water yield from the Moscow basin is about 2.6 billion gallons (12,000 acre-feet), but the percentage that could feasibly be recovered is not known. The unconsolidated shallow aquifers seemingly do not yield sufficient water to wells to warrant their consideration at this time as a source to meet large-scale demands. Furthermore, inasmuch as this shallow water is discharged chiefly into the streams of the area, it does not represent an additional independent source; any pumping of water from the shallow aquifers would reduce streamflow accordingly.

Part of the 12,000 acre-feet of surface water available annually might be used for artificial recharge of the artesian aquifers. Surface storage for recharge could be coupled with direct use of surface water in the municipal system. Efficient joint use of ground water and surface water could minimize the draft on each source and permit recovery of the artesian pressure. In general, injection wells could be used to recharge aquifers, but other methods of artificial recharge also might be applicable. Possibly not all the water injected into the artesian reservoir could be recovered because some of it might move westward through the aquifers out of the basin.

The estimate of average annual surface-water yield of the basin is only roughly indicative of the probable amount of runoff from the basin because the records on which it is based are quite inadequate. Systematic basinwide studies of the discharge and suspended-sediment load and the chemical quality of surface water in the Moscow basin should be made.

Because satisfactory and economical solution of the long-range water problems depends upon the location and development of supplementary sources of water, early initiation of an investigative program would seem worth while. Present data indicate that adequate new sources of ground water are not available within the basin. Future investigations of ground water as a source of supplemental water would, therefore, have to be made in areas outside, but adjoining, the Moscow basin. The most promising new source of water within the basin is surface water, which is yet to be adequately evaluated. A program of basic-data collection might start with systematic measurements of the discharge and suspended-sediment load of the streams in the Moscow basin. Systematic sampling and chemical analysis of the water should be done at the same time. Such a program would be the first step in acquiring a water supply adequate to meet foreseeable needs and in providing a reserve for future growth and development. 


\section{REFERENCES}

Criddle, W. D., 1947, Estimate of water requirements of crops in irrigated areas of Idaho: U.S. Soil Conserv. Service, Div. Irrigation. 13 p., 19 tables.

Fenneman, N. M., 1917, Physiographic divisions of the United States: Assoc. Am. Geographers Annals, v. 6, p. 19-98.

Foxworthy, B. L., and Washburn, R. L., 1957, Ground water in the Pullman area, Whitman County, Washington: U.S. Geol. Survey open-file report, $122 \mathrm{p}$.

Laney, F. B., Kirkham, V. R. D., and Piper, A. M., 1923, Ground-water supply at Moscow, Idaho: Idaho Bur. Mines and Geology Pamph. 8.

Pardee, J. T., and Bryan, Kirk, 1926, Geology of the Latah formation in relation to the lavas of the Columbia Plateau near Spokane, Washington: U.S. Geol. Survey Prof. Paper 140-A, p. 17-81.

Simons, W. D., 1953, Irrigation and streamflow depletion in Columbia River basin above The Dalles, Oregon: U.S. Geol. Survey Water-Supply Paper $1220,126 \mathrm{p}$.

Tullis, E. L., 1944, Contributions to the geology of Latah County, Idaho: Geol. Soc. America Bull., v. 55, p. 131-164.

U.S. Corps of Engineers, North Pacific Division, 1956, Summary report of the snow investigations. Snow Hydrology, June 30, $437 \mathrm{p}$.

U.S. Geological Survey, 1936-41, Surface water supply of the United States, 1934-40, Pt. 13, Snake River basin: Water-Supply Papers 768 (p. 191), 793 (p. 188), 813 (p. 226), 833 (p. 205), 863 (p. 225), 883 (p. 260), 903 (p. 237). 


\section{TABLE 1.-Logs of wells}

[The well logs on the following pages were obtained from drillers and well owners. The original terminology of the $\operatorname{logs}$ is modified slightly for uniformity and clarity]i

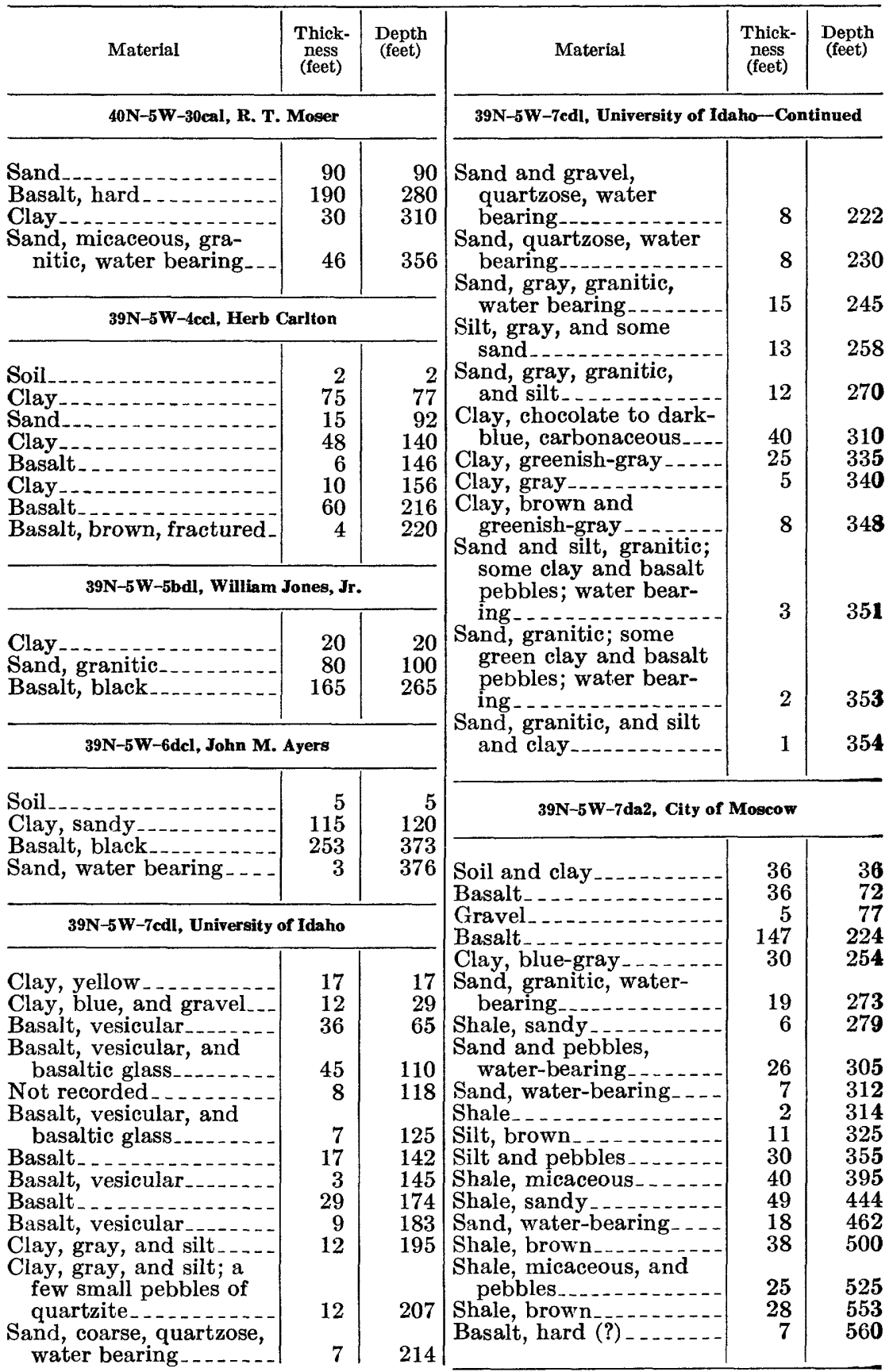


TABLe 1.-Logs of wells-Continued

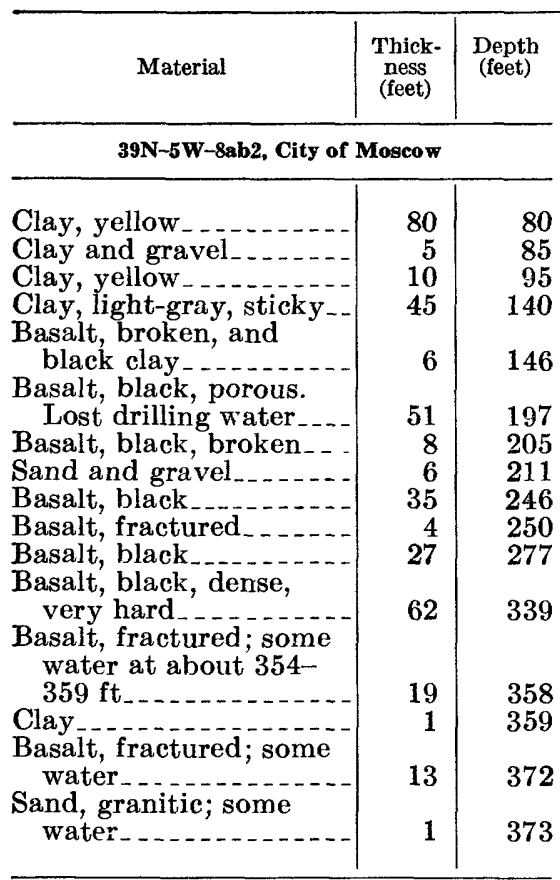

39N-5W-8bal, City of Moscow

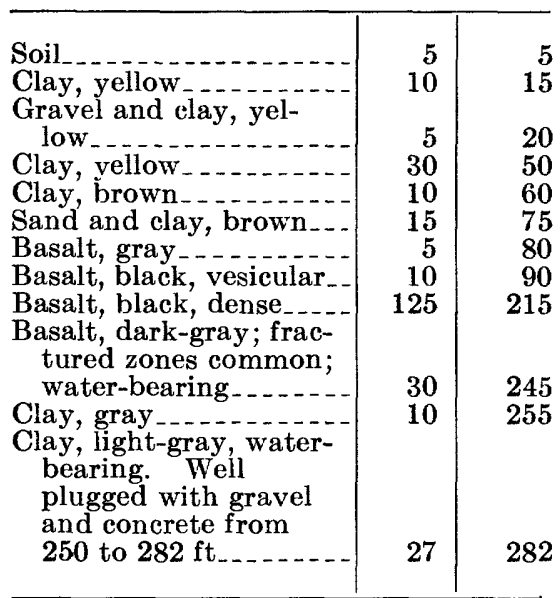

39N-5W-8dd1, City of Moscow

Soil
Clay
Clay and gravel.
Gravel
Clay, yellow
Clay, brown
Clay, black
Basalt, black

\begin{tabular}{r|r}
4 & 4 \\
6 & 10 \\
10 & 20 \\
1 & 21 \\
34 & 55 \\
5 & 60 \\
15 & 75 \\
33 & 108
\end{tabular}

\begin{tabular}{|l|c|c|} 
Material & $\begin{array}{c}\text { Thick- } \\
\text { ness } \\
\text { (feet) }\end{array}$ & $\begin{array}{c}\text { Depth } \\
\text { (feet) }\end{array}$ \\
\hline
\end{tabular}

39N-5W-8dd1, City of Moscow-Continued

\begin{tabular}{|l|r|r}
\hline Basalt, gray-_-_-_-- & 129 & 237 \\
Basalt, black, porous_-- & 9 & 246 \\
Basalt, black, dense & 4 & 250 \\
Basalt, porous, and clay_- & 8 & 258
\end{tabular}

Clay, black and brown some fragments of wood .

Clay, yellow .........

Clay, blue...........

Clay, blue-gray .......

Shale, blue ...........

Clay, gray

Clay, brown

Clay, gray

Clay, brown . ........

Clay, variegated

Basalt boulders, biak

Clay, blue.........

Clay, brown ..........

Clay, blue

Clay, sandy

Clay, brown

Clay, blue...........

Clay and sand .........

Basalt, gray, some pyrite.

Basalt, gray

Clay, brown

Clay and granitic sand.

Clay, gray and green.

Clay, brown ..........

Clay, gray $\ldots \ldots \ldots$

Clay, variegated

250

258

260

265

287

296

300

330

332

340

360

366

370

380

420

425

435

450

468

595

600

695

720

735

755

765

768

790

\begin{tabular}{|c|c|c|}
\hline \multicolumn{3}{|c|}{ 39N-5W-15ac1, Moscow Golf Course } \\
\hline Soil and clay & 61 & 61 \\
\hline Basalt _... . . & 139 & 200 \\
\hline $\begin{array}{l}\text { Sand, red, quartzose, } \\
\text { partly consolidated; } \\
\text { water bearing }\end{array}$ & 3 & 203 \\
\hline
\end{tabular}

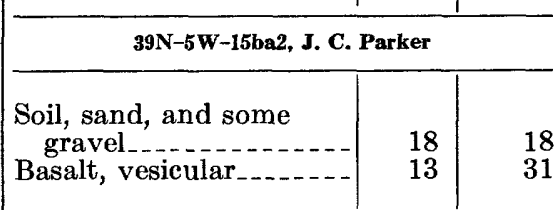

39N-5W-17da1, Sunset Memorial Gardens

\begin{tabular}{|c|c|}
\hline Soil____ & 5 \\
\hline $\begin{array}{l}\text { Clay, gray } \\
\text { Clay, brown, and some }\end{array}$ & 16 \\
\hline $\begin{array}{l}\text { gravel } \\
\text { Clay, yellow, and gravel; }\end{array}$ & 8 \\
\hline some water & 10 \\
\hline
\end{tabular}


TABLE 1.-Logs of wells-Continued

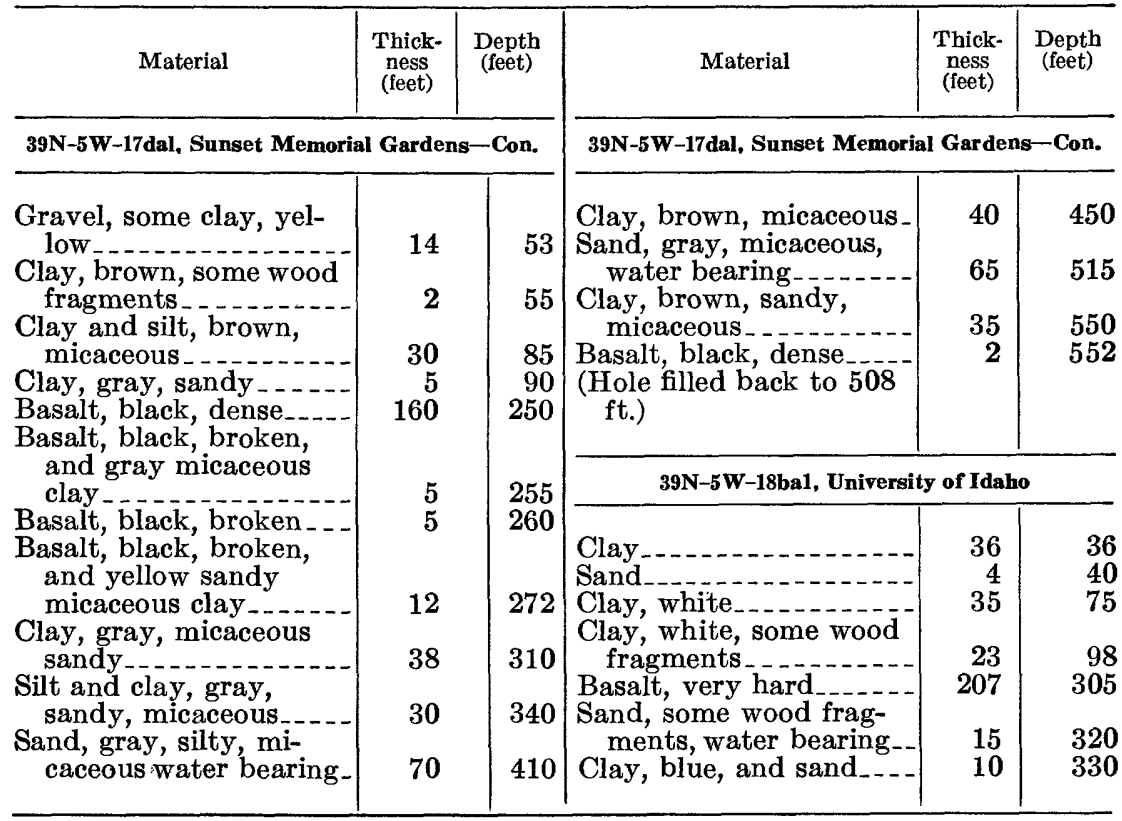


GROUND-WATER PROBLEMS, MOSCOW, IDAHO

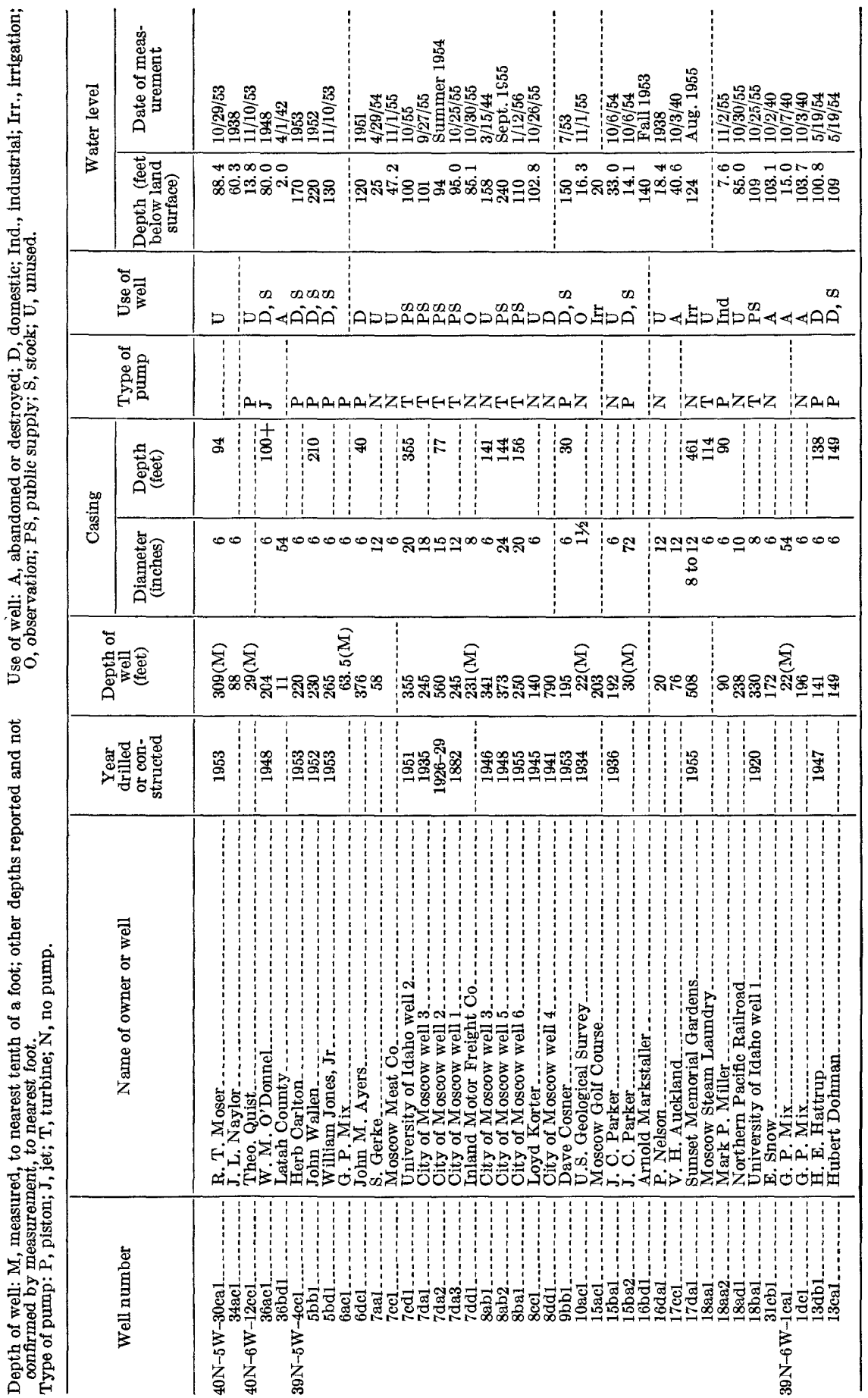





\section{INDEX}

\begin{tabular}{|c|c|}
\hline Page & Pag \\
\hline Acknowledgments. & Paradise Creek. \\
\hline Alluvium & Paradise Ridge \\
\hline $\begin{array}{l}\text { Aquifers. See Artesian aquifers, Unconfined } \\
\text { aquifers. }\end{array}$ & $\begin{array}{l}\text { Perched ground water, definition } \\
\text { Physiography }\end{array}$ \\
\hline Artesian aquifers, recharge____... 337, 340,347-348 & Piezometric surface \\
\hline $\begin{array}{l}\text { stratigraphic relations. } \\
\text { water levels. }\end{array}$ & $\begin{array}{c}\text { Pleistocene deposits, unconfined ground } \\
\text { water. }\end{array}$ \\
\hline withdrawals $. . . \ldots . . . . .331-332,345$ & $\begin{array}{l}\text { Population } \\
\text { Precipitation }\end{array}$ \\
\hline Basalt flows, origin & $\begin{array}{l}\text { Public water supply, source } \\
\text { Pullman, Wash }\end{array}$ \\
\hline Calcium bicarbonate. & \\
\hline Catchment and recharge area......... $340,341,342$ & Quality of the water \\
\hline es, ground water.............. 344 & \\
\hline $\begin{array}{l}\text { Columbia Plateau } \\
\text { Columbia River basalt } \ldots \ldots \ldots \ldots \ldots\end{array}$ & $\begin{array}{l}\text { Recharge, artesiau } \\
\quad \text { artificial }\end{array}$ \\
\hline Crystalline rocks. & $\begin{array}{l}\text { References } \\
\text { Runoff. }\end{array}$ \\
\hline $\begin{array}{l}\text { Depth to water. } \\
\text { Discharge, ground-water }\end{array}$ & Rural water supply, source \\
\hline $337-338$ & Silica content \\
\hline Drainage... & $\begin{array}{l}\text { Sublimation, loss of precipitation } \\
\text { Surface water. See Discharge, Runoff, Sus- } \\
\text { pended-sediment losd. }\end{array}$ \\
\hline leologic history & $\begin{array}{l}\text { Surficial deposits. } \\
\text { Suspended-sediment load }\end{array}$ \\
\hline $\begin{array}{l}\text { Hardness of water. } \\
\text { Hydrographs.... }\end{array}$ & $\begin{array}{l}\text { rature } \\
\text { wins }\end{array}$ \\
\hline vater supply, source........... 330, 339, 340 & Tomer Butte \\
\hline $\begin{array}{ll}\text { Injection wells } & 347 \\
\text { Interception, loss of precipitation. }\end{array}$ & Transpiration. See Evapotrans \\
\hline $\begin{array}{l}\text { tent of water. } \\
\text { n water, consumptive use }\end{array}$ & $\begin{array}{l}\text { Unconfined aquifers, recharge } \\
\quad \text { stratigraphic relationship } \\
\text { Underflow }\end{array}$ \\
\hline $\begin{array}{l}\text { Latah fermation, stratigraphic relationship.- } 332,335 \\
\text { artesian water. }\end{array}$ & $\begin{array}{l}\text { Water consumption, estimated } \\
\text { Water-level fluctuations. }\end{array}$ \\
\hline 326,328 & nentary............. 346-348 \\
\hline $341,343,345,347,349,350$ & ition $\ldots$ \\
\hline Moscow Mountain $\ldots . . . . . . . .329,330$ & $\begin{array}{l}\text { Well loss, definition } \\
\text { Wells, logs }\end{array}$ \\
\hline Palouse formation..... & numbering system .. \\
\hline $\begin{array}{l}\text { Palouse Fills. } \\
\text { Palouse Range. }\end{array}$ & records \\
\hline $\begin{array}{l}\text { Palouse Range. } \\
\text { Palouse River... }\end{array}$ & water level ........... $339,340-341,346$ \\
\hline alouse River, South Fork . . . . 327, 329, 330, 337 & -water... \\
\hline
\end{tabular}

